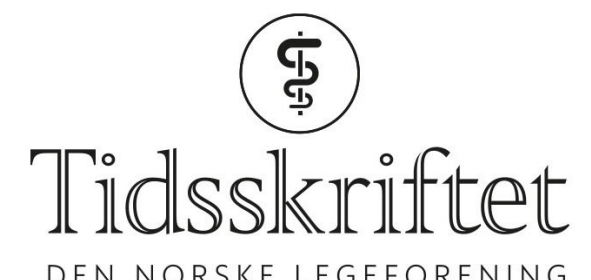

\title{
Gutt i tenårene med store ulcerasjoner i hodet og nakken
}

NOE Å LAERE AV

\section{BJØRNAR HALSØR MOEN}

E-post: bjornar.halsor.moen@helse-bergen.no Hudavdelingen

Haukeland universitetssjukehus

Bjørnar Halsør Moen er lege i spesialisering i hud- og veneriske sykdommer. Forfatteren har fylt ut ICMJE-skjemaet og oppgir ingen interessekonflikter.

\section{TONE WIKENE NYSTAD}

Revmatologisk avdeling Haukeland universitetssjukehus

Tone Wikene Nystad er ph.d., spesialist i revmatologi og overlege.

Forfatteren har fylt ut ICMJE-skjemaet og oppgir ingen interessekonflikter.

\section{TORILL MYKLESTAD BARRETT}

Avdeling for patologi

Haukeland universitetssjukehus

Torill Myklestad Barrett er spesialist i patologi og overlege.

Forfatteren har fylt ut ICMJE-skjemaet og oppgir ingen interessekonflikter.

\section{LENE FRØYEN SANDVIK}

Hudavdelingen

Haukeland universitetssjukehus

og

Klinisk institutt 1

Universitetet i Bergen

Lene Frøyen Sandvik er ph.d., spesialist i hud- og veneriske sykdommer, overlege og førsteamanuensis. Forfatteren har fylt ut ICMJE-skjemaet og oppgir ingen interessekonflikter.

Ulcerasjoner kan ha mange årsaker og kan forekomme ved sirkulatoriske, traumatiske, infeksiøse, maligne og immunologiske tilstander. Vår pasient hadde en uvanlig presentasjon med multiple ulcerasjoner i hode- og nakkeregionen. Årsaken skulle vise seg å være vanskelig å avdekke.

En tidligere frisk gutt i midten av tenårene utviklet en raskt voksende kviselignende forandring i nakken. Fastlege mistenkte abscess og lesjonen ble incidert. Lesjonen fortsatte imidlertid å utvikle seg til en dyp, smertefull ulcerasjon. Det oppsto de neste ukene flere lignende lesjoner som åpnet seg spontant og tømte seg for rikelige mengder puss både i nakken, lateralt på halsen, preaurikulært og til sist i pannen. Alle elementene utviklet seg i løpet av kort tid til intenst smertefulle ulcerasjoner. Pasienten ble vurdert av lokal hudlege, som tok dyrkningsprøve som viste oppvekst av gule stafylokokker. På mistanke om ektyma 
ble det startet tablettbehandling med dikloksacillin, men det var ingen bedring etter én ukes behandling. Han ble innlagt på en hudavdeling som øyeblikkelig hjelp med mistanke om ektyma eller pyoderma gangrenosum.

Ved infeksjon i hud og bløtdeler er vanligste agens streptokokker eller gule stafylokokker. Tegn på dype og mer alvorlige infeksjoner kan være kraftige smerter som ikke står i forhold til kliniske funn, rask progresjon, oppløsning av intakt hudstruktur og kutan gassproduksjon. Anamnese er viktig for å avdekke potensielle smittekilder. Dette vil ha betydning for mikrobiologiske undersøkelser og behandling (1).

Pasienten bodde på gård med katt og sauer i omgivelsene. I forbindelse med fritidsaktiviteter brukte han sporadisk hjelm. Pasienten hadde ikke vært på reise, og hadde ingen forutgående leddsmerter, luftveissymptomer eller endring i avføringsmønster. Han hadde gått på skole inntil få dager før innleggelsen. Det var ingen hereditet for sykdom i familien.

Ved innleggelsen var pasienten i god allmenntilstand med puls $120 \mathrm{slag} / \mathrm{min}$, blodtrykk 130/80 mm Hg, rektaltemperatur 37, ${ }^{\circ} \mathrm{C}$ og respirasjonsfrekvens $16 \mathrm{pust} / \mathrm{min}$.

Kroppsmasseindeks var $28 \mathrm{~kg} / \mathrm{m}^{2}$. Det var normale funn ved unders $\emptyset$ kelse av munnhulen, hjertet, lungene, buken og underekstremitetene, og det var ingen lymfadenopati i armhulene eller lysken. Lymfeknuter over halsen lot seg ikke palpere grunnet intense smerter.

Gutten hadde multiple, purulente, nekrotiske ulcerasjoner i nakken, preaurikulært og i pannen (figur $1 \operatorname{og} 2$ ).
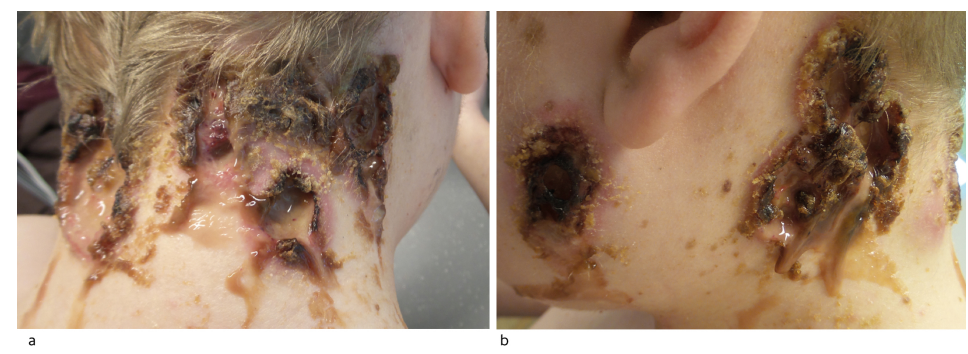

Figur 1 Ulcerasjoner i nakken (a) og preaurikulcert (b) ved innkomst. Det var rikelig med purulent sekresjon. Sårkanter og sårbunn var dekket av tykke, gulbrune kruster.



Figur 2 Ulcerasjoner i pannen (a) og nakken (b) etter sårstell dag 4. Sårkanter var moderat erytematøse, eleverte og steile. Flere steder var sårkanter underminerte. Sårbunnen var dekket med nekrose og fibrin. Åpne komedoner i pannen.

Blodprøver viste leukocytter $12,4 \cdot 10^{9} / \mathrm{l}$ (referanseområde $\left.4,4-10,5 \cdot 10^{9} / 1\right)$, nøytrofile granulocytter $9,2 \cdot 10^{9} / 1\left(2,1-7,1 \cdot 10^{9} / 1\right)$, monocytter $1,26 \cdot 10^{9} / 1\left(0,3-0,6 \cdot 10^{9} / 1\right)$ og CRP $52 \mathrm{mg} / \mathrm{l}(<$ 5), men ellers normale verdier av trombocytter, kreatinin, ALAT og karbamid. Urinstiks viste ${ }_{2+}^{+}$på proteiner, ellers normale funn.

Ulcerasjonene hadde oppstått i nær relasjon til trykkpunkt fra hjelm og i områder med akne i pannen. Dette gav mistanke om patergi. På bakgrunn av anamnese, kliniske funn og tilnærmet normale infeksjonsparametre ble det mistenkt immunologiske sår, mest sannsynlig atypisk pyoderma gangrenosum.

Pyoderma gangrenosum er en sjelden, ulcerativ hudsykdom av ukjent etiologi. Sykdommen tilhører gruppen nøytrofile dermatoser, som histologisk er assosiert med nøytrofil infiltrasjon, men uten tegn til infeksjon (2). Pyoderma gangrenosum er hyppig assosiert med inflammatorisk tarmsykdom, inflammatorisk artritt og malignitet. Karakteristisk for 
sykdommen er at den kan starte eller blusse opp i et område utsatt for traume, såkalt patergi. Patergi kan eksempelvis oppstå i et operasjonsarr, rundt en stomi eller ved trykk mot hud. Den ulcerative varianten av pyoderma gangrenosum debuterer ofte som en pustel. Ulcerasjonen er karakterisert av et purulent og nekrotisk område sentralt, omgitt av en rød-lilla, ofte irregulær sårkant med underminering (3). Pyoderma gangrenosum er oftest lokalisert til underekstremiteter, og kun i $5 \%$ av tilfellene beskrevet i hode- eller nakkeregionen (4). Vanligvis trenger pasienter behandling med immunsuppressive legemidler, hvorav prednisolon er førstevalget (3).

Lokalisasjonen av ulcerasjonene samt sårkantenes utseende var ikke typisk for pyoderma gangrenosum. Derfor ble infeksjon, malignitet og vaskulitt vurdert som mulige differensialdiagnoser. Bakteriologisk dyrkning av puss viste sparsom vekst av normal hudflora forenlig med kolonisering. Det var ikke oppvekst av Actinomyces eller Nocardia, og soppdyrkning var negativ. Det var ikke holdepunkter for mykobakterier, og blodkulturer var negative.

CT caput, collum, thorax og abdomen viste ingen dype abscesser eller tegn til malignitet. Som bifunn ble det beskrevet en $8 \mathrm{~mm}$ kantet lesjon apikalt i høyre lunge. MR caput og collum viste heller ikke dypere abscesser eller tegn til malignitet. Som bifunn ble det beskrevet lett slimhinnefortykkelse i taket av venstre sfenoidalsinus. Histologisk undersøkelse av hudbiopsier avdekket ikke tegn til vaskulitt, granulomatøs inflammasjon eller malignitet, men undersøkelsen kunne ikke utelukke diagnosen pyoderma gangrenosum.

Det ble ved innleggelse startet behandling med prednisolon $50 \mathrm{mg} \times 1$, som over åtte dager ble $ø$ kt til go $\mathrm{mg} \times 1(1 \mathrm{mg} / \mathrm{kg})$. Pasienten fikk smertepumpe, og sårskift ble utført i narkose. Behandlingen med dikloksacillin ble kontinuert. Ulcerasjonene ble behandlet med hydrogel under polyuretanplater; senere ble hydrogel erstattet av takrolimussalve o,1\%. Etter 14 dagers behandling var det god bedring med avtagende inflammasjon i sårkanter og begynnende epitelialisering fra kantene. Fremdeles var ulcerasjonene smertefulle, og sårskift måtte gjøres i narkose. Prøver for anti-nøytrofilt cytoplasma-antistoff (ANCA) ble besvart på samme tid og viste positiv anti-proteinase 3 (PR3-ANCA) $(5,1 \mathrm{IE} / \mathrm{ml}$, referanseområde $<1$ ).

ANCA er spesielt assosiert med primære vaskulitter i små til middels store kar og sees ved tilstandene granulomatøs polyangiitt (tidligere kalt Wegeners granulomatose), mikroskopisk polyangiitt og eosinofil granulomatose med polyangiitt (tidligere kalt Churg-Strauss-syndrom) (5). Hos pasienter med granulomatøs polyangiitt med ANCA har 80-90 \% PR3-ANCA $(6,7)$. Imidlertid kan ANCA også forekomme ved blant annet infeksiøse, maligne og andre autoimmune sykdommer (8-10).

Det ble diskutert tverrfaglig om tilstanden kunne være ledd i granulomatøs polyangiitt. Pasienten hadde ikke passende symptomer eller funn fra øvre eller nedre luftveier, og kontroll av kreatinin og urinstiks samt mikroskopi av urin gav ikke mistanke om nefritt. Nyrebiopsi var derfor ikke indisert. I tillegg var det ikke histologiske funn i hudbiopsiene som understøttet diagnosen granulomatøs polyangitt. Den tentative diagnosen pyoderma gangrenosum ble derfor opprettholdt. Pasienten ble fortsatt behandlet med høye doser prednisolon, og for å redusere risiko for potensielle bivirkninger ble behandlingen supplert med infusjon av infliksimab $5 \mathrm{mg} / \mathrm{kg}$. Én uke senere ble smertepumpen seponert og prednisolondosen redusert. Ved utskrivelse etter seks ukers opphold var ulcerasjonene fortsatt under fin tilheling. Gutten ble fulgt videre med polikliniske kontroller og var tiltenkt behandling med infliksimab intravenøst hver åttende uke med samtidig gradvis reduksjon av prednisolondosen.

Ved kontroll én måned etter utskrivelse hadde tilstanden forverret seg med økende smerter og sekresjon. Prednisolondosen ble derfor $\emptyset \mathrm{kt}$ fra 20 til $40 \mathrm{mg}$ daglig. I tillegg hadde han utviklet sinusittsymptomer og hodepine. Muligheten for granulomatøs polyangiitt ble igjen drøftet tverrfaglig. CT av ansiktsskjelettet viste utfylling av flere sinuser, men ingen tegn til skjelettdestruksjon. Biopsi fra luftveisslimhinne var uten vesentlige patologiske 
forandringer. Det ble mistenkt bakteriell sinusitt sekundært til immunsuppresjon. Denne ble fors $ø$ kt behandlet med dikloksacillin og deretter klaritromycin kombinert med daglig saltvannsskylling, flutikasonfuroat og oksymetazolin-nesespray, men pasienten hadde ikke effekt av behandlingen. Man fant fortsatt ikke sikkert grunnlag for diagnosen granulomatøs polyangiitt siden sinusittsymptomene var akutt oppstått, og fordi hudforandringene både morfologisk og i biopsi kunne passe med pyoderma gangrenosum.

Granulomatøs polyangiitt er en nekrotiserende vaskulittsykdom. Etiologien er ukjent, og tilstanden er sjelden: I en svensk studie var insidensen for barn (o-17 år) 1,4 per million (11). Diagnosen stilles vanligvis på bakgrunn av kliniske funn som inflammasjon i øre-nese-halsområdet, forandringer i nedre luftveier eller nefritt - i kombinasjon med forhøyede inflammasjonsparametre og positiv ANCA, og helst bekreftet med positiv biopsi fra et affisert organ. Det er vanlig med allmennsymptomer som feber, utmattelse og vekttap. Hudmanifestasjoner kan forekomme i 14-50 \% av tilfellene og er hyppigst lokalisert til underekstremiteter. Vanligste kutane lesjoner er palpabel purpura, men symptombildet kan være polymorft og omfatte blant annet pyoderma gangrenosum-lignende ulcerasjoner, papler, noduli, vesikler, bullae, petekkier, erytem og livedo reticularis (12-16). Hos barn er det beskrevet acneiforme og follikulittlignende papler (17). Oral affeksjon kan forekomme i form av ulcerasjon eller gingivitt $(14,18,19)$. Granulomatøs polyangiitt er ubehandlet assosiert med høy mortalitet. Tidlig diagnose og behandling har betydning for å forhindre irreversibel organskade (20).

Én måned senere var ulcerasjonene nærmest tilhelet. Imidlertid hadde gutten i løpet av få dager utviklet komplett visustap på venstre øye. MR orbita viste utfylte sinuser, kontrastladning langs planum sphenoidale og antatt affeksjon av nervus opticus. Han ble operert med dekompresjon av nerven, og det ble funnet polypøst vev i det aktuelle området. Biopsi viste nekrose med antydning til geografisk karakter, men ingen tydelig vaskulitt eller tegn til granulomer. Uttalt behandlingsrefraktær sinusitt i kombinasjon med positiv ANCA og histologi gjorde at pasienten nå fikk diagnosen granulomatøs polyangiitt. Behandlingen ble endret til metylprednisolon og rituksimab. Forsøksvis fikk han også initialt tre doser syklofosfamid for raskere behandlingseffekt. Pasienten hadde god effekt av nytt behandlingsregime, både med hensyn til visus og sinusittsymptomer, og ulcerasjonene ble fullstendig tilhelet.

\section{Diskusjon}

Hos vår pasient debuterte granulomatøs polyangiitt på en svært uvanlig måte. Pasienten utviklet multiple, purulente, nekrotiske ulcerasjoner i hode-nakke-regionen som vi best kunne beskrive som atypisk pyoderma gangrenosum. Gjennom senere litteraturs $ø \mathrm{k}$ fant vi at Perry og medarbeidere i 1968 beskrev en tilstand med ulcerasjoner som han gav navnet malign pyoderma. Dette bildet var karakterisert ved pyoderma gangrenosum-lignende ulcerasjoner i hode-nakke-regionen eller øvre del av truncus. Typisk var det ulcerasjoner preaurikulært (21). Dette samsvarer helt med funnene hos vår pasient. Det er flere kasuistikker som beskriver malign pyoderma som manifestasjon av granulomatøs polyangiitt (22-26).

Biopsi fra affisert hud ved granulomatøs polyangiitt kan i opptil $50 \%$ av tilfellene vise leukocytoklastisk vaskulitt, i noen tilfeller granulomatøs inflammasjon, og i sjeldne tilfeller geografisk nekrose. Histologiske undersøkelser kan også vise uspesifikke perivaskulære lymfocyttinfiltrater. Direkte immunfluorescens av hudbiopsi kan gi nedslag av IgM og komplementfaktor $\mathrm{C}_{3}$ rundt små kar i dermis $(13,14)$. Hos vår pasient ble det ikke funnet typiske tegn til granulomatøs polyangiitt i biopsier tatt fra hud og neseslimhinne, kun i biopsier fra slimhinne fra sinus, som avdekket geografisk nekrose. Ved ny gjennomgang av hudbiopsier etter at diagnosen granulomatøs polyangiitt var stilt, ble det funnet tegn til geografisk nekrose. Kasuistikken er en påminnelse om at differensialdiagnoser ikke kan utelukkes på bakgrunn av uspesifikke histologiske funn. Den illustrerer at granulomatøs polyangiitt kan være en diagnostisk utfordring og kreve et bredt tverrfaglig samarbeid. 


\section{LITTERATUR:}

1. Stevens DL, Bisno AL, Chambers HF et al. Practice guidelines for the diagnosis and management of skin and soft-tissue infections. Clin Infect Dis 2005; 41: 1373-406. [PubMed][CrossRef]

2. Prat L, Bouaziz JD, Wallach D et al. Neutrophilic dermatoses as systemic diseases. Clin Dermatol 2014;32:376-88. [PubMed][CrossRef]

3. Brooklyn T, Dunnill G, Probert C. Diagnosis and treatment of pyoderma gangrenosum. BMJ 20o6; 333: 181-4. [PubMed][CrossRef]

4. von den Driesch P. Pyoderma gangrenosum: a report of 44 cases with follow-up. Br J Dermatol 1997; 137: 1000-5. [PubMed][CrossRef]

5. Seo P, Stone JH. The antineutrophil cytoplasmic antibody-associated vasculitides. Am J Med 2004; 117:39-50. [PubMed][CrossRef]

6. Wegener's Granulomatosis Etanercept Trial Research Group. Limited versus severe Wegener's granulomatosis: baseline data on patients in the Wegener's granulomatosis etanercept trial. Arthritis Rheum 2003; 48: 2299-309. [PubMed][CrossRef]

7. Damoiseaux J, Csernok E, Rasmussen N et al. Detection of antineutrophil cytoplasmic antibodies (ANCAs): a multicentre European Vasculitis Study Group (EUVAS) evaluation of the value of indirect immunofluorescence (IIF) versus antigen-specific immunoassays. Ann Rheum Dis 2017; 76: 647-53. [PubMed][CrossRef]

8. Knight A, Ekbom A, Brandt L et al. What is the significance in routine care of c-ANCA/PR3-ANCA in the absence of systemic vasculitis? A case series. Clin Exp Rheumatol 2008; 26 (suppl 49): S53-6. [PubMed]

9. Mahr A, Batteux F, Tubiana S et al. Brief report: prevalence of antineutrophil cytoplasmic antibodies in infective endocarditis. Arthritis Rheumatol 2014; 66:1672-7. [PubMed][CrossRef]

10. Hoffman GS, Specks U. Antineutrophil cytoplasmic antibodies. Arthritis Rheum 1998; 41:1521-37. [PubMed][CrossRef]

11. Mossberg M, Segelmark M, Kahn R et al. Epidemiology of primary systemic vasculitis in children: a population-based study from southern Sweden. Scand J Rheumatol 2018; 47: 295-302.

[PubMed][CrossRef]

12. Zycinska K, Wardyn K, Zielonka TM et al. Cutaneous changes: an initial manifestation of pulmonary Wegener's granulomatosis. Adv Exp Med Biol 2013; 755:307-10. [PubMed][CrossRef]

13. Daoud MS, Gibson LE, DeRemee RA et al. Cutaneous Wegener's granulomatosis: clinical, histopathologic, and immunopathologic features of thirty patients. J Am Acad Dermatol 1994; 31 : 605-12. [PubMed][CrossRef]

14. Marzano AV, Raimondo MG, Berti E et al. Cutaneous manifestations of ANCA-associated small vessels vasculitis. Clin Rev Allergy Immunol 2017; 53: 428-38. [PubMed][CrossRef]

15. Comfere NI, Macaron NC, Gibson LE. Cutaneous manifestations of Wegener's granulomatosis: a clinicopathologic study of 17 patients and correlation to antineutrophil cytoplasmic antibody status. J Cutan Pathol 2007;34: 739-47. [PubMed][CrossRef]

16. Genovese G, Tavecchio S, Berti E et al. Pyoderma gangrenosum-like ulcerations in granulomatosis with polyangiitis: two cases and literature review. Rheumatol Int 2018; 38: 1139-51. [PubMed][CrossRef]

17. Wright AC, Gibson LE, Davis DM. Cutaneous manifestations of pediatric granulomatosis with polyangiitis: a clinicopathologic and immunopathologic analysis. J Am Acad Dermatol 2015; 72: 859-67. [PubMed][CrossRef]

18. Stewart C, Cohen D, Bhattacharyya I et al. Oral manifestations of Wegener's granulomatosis: a report of three cases and a literature review. J Am Dent Assoc 2007; 138:338-48. [PubMed][CrossRef] 19. Patten SF, Tomecki KJ. Wegener's granulomatosis: cutaneous and oral mucosal disease. J Am Acad Dermatol 1993; 28: 710-8. [PubMed][CrossRef] 
20. Mukhtyar C, Flossmann O, Hellmich B et al. Outcomes from studies of antineutrophil cytoplasm antibody associated vasculitis: a systematic review by the European League Against Rheumatism systemic vasculitis task force. Ann Rheum Dis 2008; 67: 1004-10. [PubMed][CrossRef]

21. Perry HO, Winkelmann RK, Muller SA et al. Malignant pyodermas. Arch Dermatol 1968; 98: 561-76. [PubMed][CrossRef]

22. Salassa JR, Winkelmann RK, McDonald TJ. Malignant pyoderma. Otolaryngol Head Neck Surg 1981; 89: 917-22. [PubMed][CrossRef]

23. Gibson LE, Daoud MS, Muller SA et al. Malignant pyodermas revisited. Mayo Clin Proc 1997; 72: 734-6. [PubMed][CrossRef]

24. Mantovani L, Zauli S, Sarno O et al. Treatment of a relapsing facial pyoderma gangrenosum (malignant pyoderma). Int J Dermatol 2013; 52: 753-6. [PubMed][CrossRef]

25. Kędzierska K, Sindrewicz K, Smektała T et al. Wegener's granulomatosis and pyoderma gangrenosum-rare causes of facial ulcerations. Postepy Hig Med Dosw 2016; 70: 210-8. [PubMed][CrossRef]

26. de Boysson H, Martin Silva N, de Moreuil C et al. Neutrophilic dermatoses in antineutrophil cytoplasmic antibody-associated vasculitis: A French multicenter study of 17 cases and literature review. Medicine (Baltimore) 2016; 95: e2957. [PubMed][CrossRef]

Publisert: 8. april 2019. Tidsskr Nor Legeforen. DOI: 10.4045/tidsskr.18.0647

Mottatt 16.8.2018, første revisjon innsendt 12.11.2018, godkjent 3.12.2018.

(C) Tidsskrift for Den norske legeforening 2020. Lastet ned fra tidsskriftet.no 